\title{
Refuge in Europe? Church Asylum as Human Rights Work in Fortress Europe
}

\author{
Verena Mittermaier
}

\section{More Than Twenty-five Years of Church Asylum in Germany}

On August 30, 1983, Cemal Altun, a twenty-three-year-old Turkish asylum seeker, jumped out of a window of a Berlin court building, ending his life. His imminent deportation to a state where he feared political persecution led him to this drastic step. For the Protestant parish of Heiligkreuz (Holy Cross) in Berlin this was a decisive moment. The parish had supported Cemal Altun in his asylum application, and his death had a dramatic effect. Within months, the parish took in three Palestinian families facing deportation to Lebanon. This was the first church asylum incident to occur in Germany. ${ }^{1}$

It is now over twenty-five years later and a great deal has changed, including the general context of asylum policy in Europe, the number of asylum seekers in Germany, and the mechanisms both to get rid of them and to prevent others from arriving.

Despite these changes, parishes still often face difficult decisions, like those confronting Heiligkreuz when it decided to accord church asylum. When making such a decision, offering immediate and tangible protection-a room, a flat in the parish-is still often the first and most pressing step in protecting people from wrongful deportation and exposure to a dangerous situation. The next steps involve legal assistance, dealing with authorities, and organizing daily life, including shopping, school attendance, and medical care. Later, public relations and networking need to be managed, information must be provided, fundraising must be engaged in, and religious services and silent vigils must be orchestrated. All of this requires the enthusiasm of many-mostly volunteer-supporters. ${ }^{2}$

In 1994, the German Ecumenical Committee on Church Asylum was founded. Since that time, regular evaluations conclude that church asylum remains a crucial means of ensuring refugee protection. Over 80 per cent of the thirty to sixty cases of church asylum that take place annually in Germany achieve a positive result. ${ }^{3}$ The year 2007 saw fortythree cases of church asylum. Of these, twenty-one were ongoing cases, three began that year, eighteen were resolved positively, and one was resolved negatively. Church asylum was offered in 2007 by at least twenty-seven Protestant churches, four Catholic parishes, one monastery, and four ecumenical networks. Protection was provided to at least 133 persons, with 74 children among them. Apart from these public cases of church asylum many parishes housed undocumented persons in guest apartments. In addition, there are cases of unpublicized church asylum that are hard to document. ${ }^{4}$ What these figures show is that again and again various parishes, sometimes in an ecumenical network, offer church asylum in Germany.

\section{"Fortress Europe": Shielding Policies against Refugees}

To give refugees who turn to parishes or monasteries a new perspective became for the most part more difficult and requires persistence. Frequently it is unavoidable to go through several official channels. In many federal states the right to stay is attached with unrealizable conditions. Moreover, the Federal Office for Migration and Refugees often cancels asylum status which it has already granted (the so-called "recall proceedings" or "cancellation proceedings").

These examples illustrate the tendency towards rejecting and expelling refugees. In this respect, Germany shares the asylum policies of neighbouring countries. "Fortress Europe" tries with all its might to seal its borders against migrants (except for highly qualified professionals). Asylum policy participates in this more general exclusionary policy of preventing migration.

To give effect to its exclusionary asylum policies, the proponents of "Fortress Europe" adopt three strategies: ${ }^{5}$ 
1. The living conditions faced by refugees already residing in Europe are made as difficult as possible in order to deter further asylum seeking. In Germany, these difficult living conditions include camp housing, prohibitions against working, limitations on free movement, reduced and restricted welfare benefits in comparison to those received by local people, and restriction of health care services to the treatment of acute disease and severe pain only. Taken together, it is hoped that word of harsh living conditions will reach countries of origin and thereby discourage further asylum seeking by nationals of these countries.

2. Asylum law in Western Europe is given increasingly exclusionary interpretations. For example, the term "political persecution" has been interpreted in an excessively narrow manner. As a result, the number of those granted asylum on this basis tends to zero. Similarly, the notion of "safe" countries has been interpreted and applied expansively to block access of many asylum seekers to the regular asylum procedures. This includes, for example, the so-called "safe third country regulation" and the concept of "safe countries of origin." Particularly troubling is that if refugees enter Germany via a "safe third country" they don't get the opportunity to present their reasons for seeking asylum. Rather, they are only asked about the route of escape and are then deported to countries where they are presumed to have been safe, regardless of whether they would actually be safe in those countries.

3. The external borders of Europe are being closed off with increased vigour in the fight against so-called "illegal immigration." This fight is being waged with real fences, armed border patrols, aircraft, warships, satellite-controlled air reconnaissance, etc. Through FRONTEX, the European Agency for the Management of Operational Co-operation at the External Borders, the EU states have embarked upon even more intense co-operation in their bids to sea external borders through air and sea reconnaissance.

\section{Dying at the Outer European Borders}

The Church Asylum Movement in its solidarity work with refugees should not be content with accomplishing positive outcomes for a small number of asylum seekers who have reached Western countries and who face particularly acute risks. In addition to working with individual asylum seekers, all the larger exclusionary strategies must be kept in view and must be fought politically in association with other refugee protection organizations.

In 2007, the German Ecumenical Committee on Church Asylum organized two conferences that, under the slogan "SOS-Refugees in Emergency-Stop the Dying at the Borders," carefully examined the policies directed at turning away refugees at the outer EU borders. These conferences highlighted the large number of fatalities that result when refugees try desperately to reach Europe by sea.

The International Center on Migration Policy Development estimates that annually 100,000 to 120,000 persons try to reach Europe over the Mediterranean Sea. Within the last ten years these attempts ended fatally for around 10,000 people. ${ }^{6}$ This, of course, is not the only route to Europe. Near the Canary Islands and at mainland borders many people regularly die as they try to reach the EU. FRONTEX is mandated to ensure that as few people as possible reach the territorial waters of the EU. The FRONTEX control and defence activities force asylum seekers and other migrants into smaller boats and onto more dangerous routes. Accordingly, there is continuous increase in fatalities.

In May of 2007 the German Ecumenical Committee on Church Asylum proposed, under the slogan "Let not the deep swallow me up ...," memorial services for drowned refugees-a suggestion that has since been adopted in many places. $^{7}$

Along similar lines, PRO ASYL, the main German refugee protection organization with which we are linked, has waged a major campaign on this issue, called "Stop the Deathtrap." 8 The main demands of the campaign are that FRONTEX cease engaging in human rights violations, that shipwrecked people be rescued unconditionally, and that refugees be offered access to a fair asylum procedure.

\section{Conclusion}

Effective political mobilization requires networking and alliances. This was a lesson learned by parishes-including the Heiligkreuz in Berlin-that have provided church asylum to individual refugees. It is a lesson that applies equally to groups in Germany, across Europe, and worldwide, seeking to challenge exclusionary asylum policies in general and the dying that is ongoing at the EUs external borders in particular.

\section{Notes}

1. Ökumenische Bundesarbeitsgemeinschaft Asyl in der Kirche e.V. (ed.), Asyl in der Kirche. Eine Dokumentation (Karlsruhe, 2004), 18.

2. ÖkumenischeBundesarbeitsgemeinschaft Asylin der Kirche e.V. (ed.), "Erstinformation Kirchenasyl. Handreichung 
für Gemeinden und ihre Gremien," Nachdruck (Berlin, October 2006); German Ecumenical Committee on Church Asylum (ed.), "Basic information on Church Asylum" (Berlin, 2007).

3. See, for example, Wolf Dieter Just and Beate Sträter, "Unter dem Schatten deiner Flügel...”: Eine empirische Untersuchung über Erfolg und Misserfolg von Kirchenasyl (Bonn, 2001).

4. See Über Kirchenasyl/Zahlen, <http://www.kirchenasyl.de>, (accessed October 24, 2008).

5. Cf. Wolf-Dieter Just, "Flüchtlingsdramen an den Außengrenzen und Europäische Menschenrechtsrhetorik," in SOS - Flüchtlinge in Not! Das Sterben an den Grenzen stoppen, Konferenzdokumentation, Ökumenische Bundesarbeitsgemeinschaft Asyl in der Kirche (ed.) (Berlin, 2008).

6. Cf. <http://www.proasyl.de/fileadmin/proasyl/fm_edakteure/ syl_in_Europa/Frontex/Zusammenfassung_Gutachten. pdf $>$ (accessed October 28, 2008).
7. Ökumenische Bundesarbeitsgemeinschaft Asyl in der Kirche e.V. (ed.), "Lass die Tiefe mich nicht verschlingen ... Anregungen für einen Gottesdienst zum Gedenken an ertrunkene Flüchtlinge" (Berlin, 2007); also in Fanny Dethloff/ and Verena Mittermaier, eds., Zähle die Tage meiner Flucht... Gottesdienstmaterialien zum Thema Flucht und Asyl (Karlsruhe 2008), 26ff.

8. See, in German and English, <http://www.stoppt-dassterben.eu>.

Verena Mittermaier is Secretary-General of the German Ecumenical Committee on Church Asylum (Ökumenische Bundesarbeitsgemeinschaft Asyl in der Kirche e.V.), Berlin. 